\title{
Short Communication: Modification of Genetic Evaluation of Herd Life from a Three-Trait to a Five-Trait Model in Canadian Dairy Cattle
}

\author{
A. Sewalem, ${ }^{*}{ }^{1}$ F. Miglior, ${ }^{\star} \dagger$ G. J. Kistemaker, $\dagger$ P. Sullivan, $\dagger$ G. Huapaya, $\dagger$ and B. J. Van Doormaal $\dagger$ \\ *Agriculture and Agri-Food Canada, Dairy and Swine Research and Development Centre, Sherbrooke, Quebec, Canada, J1M 1 Z3 \\ †Canadian Dairy Network, Guelph, Ontario, Canada, N1G 4T2
}

\begin{abstract}
The national genetic evaluation of herd life for Canadian dairy breeds was modified from a 3-trait to a 5trait animal model. The genetic evaluation incorporates information from daughter survival (direct herd life) and information from conformation, fertility, and udder health traits that are related to longevity (indirect herd life). Genetic evaluations for direct herd life were based on cows' survival from first calving to 120 days in milk (DIM), from 120 to 240 DIM, from 240 DIM to second calving, survival to third calving, and survival to fourth calving, which were analyzed using a multiple-trait animal model. Sire evaluations obtained for each of the 5 survival traits were combined into an overall sire evaluation for direct herd life. Sire evaluations for indirect herd life were based on an index of sire evaluations for dairy strength, feet and legs, overall mammary, rump angle, somatic cell score, milking speed, nonreturn rate in cows, and interval from calving to first service. A multiple-trait sire model based on multipletrait across-country evaluation methodology was used to combine direct and indirect genetic evaluations for herd life into an overall genetic evaluation for herd life. Sire evaluations for herd life were expressed as an estimated transmitting ability for the number of lactations. The transmitting ability represents expected differences among daughters for herd life; and the average herd life was set to 3 lactations.
\end{abstract}

Key words: herd life, longevity, genetic evaluation, multiple-trait animal model

Longevity or herd life is a highly desirable trait that considerably affects overall profitability (Congleton and King, 1984; Allaire and Gibson, 1992). With increased longevity, the mean production of the herd increases. Furthermore, the economic importance of herd life compared with milk production is considered higher than

Received November 1, 2006.

Accepted December 20, 2006.

${ }^{1}$ Corresponding author: sewalem@cdn.ca other nonproduction traits (van Arendonk, 1991; Allaire and Gibson, 1992; Dekkers, 1993).

Longevity can be measured in several ways (VanRaden and Klaaskate, 1993; Brotherstone et al., 1998; Vollema et al., 2000; Ducrocq, 2002; VanRaden et al., 2006) and genetic evaluation systems are not standardized across countries, which makes the comparison of sire rankings difficult. In Canada, the survival of cows in each of the first 3 lactations [survival through first lactation (S1), survival through second lactation (S2), and survival through third lactation (S3)] are recorded as a binary traits and evaluated with a multiple-trait linear animal model in which survival in each lactation is considered as a separate trait (Jairath et al., 1998). For the traits S1, S2, and S3 the cow must initiate the second, third, and fourth lactations, respectively. Hereafter, we refer to this as the old system of evaluation of herd life in Canada.

An international genetic evaluation for longevity using direct herd life (DHL) carried out by the Interbull Centre in February 2005 (International Bull Evaluation Service, 2005) showed that, for Canada, the correlations with other countries were higher than correlations among most other countries. The report also showed that, compared with other countries, the Canadian system results are in favorable EBV correlation with other countries. However, with the old system of genetic evaluation for herd life, a 2-yr opportunity window was used to determine if a subsequent calving occurred, thus delaying when Canadian bulls might get their first genetic evaluations for herd life. The outcome of this extended period, before newly proven sires have direct survival data in their EBV, was that newly proven Canadian sires did not receive an international evaluation for DHL as quickly as newly proven bulls in other countries. The objective of the present study was to improve the genetic evaluation of herd life by breaking the first lactation into 3 periods; from first calving to $120 \mathrm{DIM}$ $\left(\mathbf{S 1}_{\mathbf{a}}\right)$, from 120 to 240 DIM ( $\left.\mathbf{S 1}_{\mathbf{b}}\right)$, and from 240 DIM to second calving $\left(\mathbf{S 1}_{\mathbf{c}}\right)$, thus including direct survival data into a bull's genetic evaluation earlier. Hereafter, we refer to this as the new system of evaluation of herd life in Canada. 
Data for genetic parameter estimations were obtained from lactation records extracted for the official Canadian February 2005 genetic evaluation of herd life in the Holstein breed. The extract was modified to contain all production traits such as breed-corrected average (BCA), mature-equivalent yields, 305-d yields, and total cumulative yields for milk, fat, and protein (in $\mathrm{kg}$ ). The primary production information used was BCA of the cow; if BCA yields were missing, then matureequivalent yields, 305-d yields, or total cumulative yields were used. In all cases, the yields were then converted to BCA units. First-lactation records with calving age from 18 to 40 mo were used.

Censored records included cows that were sold for dairy purposes, exported, or leased, as well as cows still present in the herd. A lifetime record was considered completed if the cow received a termination code, indicating that she was culled or had died for any reason. For cases in which cows completed a given lactation but failed to initiate the next lactation, cows were considered culled if the latest recorded test-day record was more than 6 mo before the end of the study. Herds with at least 5 calvings in a given quota year (July to June) were assumed to be on test during that year.

The methodology that was developed for computing genetic evaluations for herd life consisted of 3 major steps: 1) computation of genetic evaluations for DHL based on survival of daughters; 2) computation of genetic evaluations for indirect herd life (IHL) based on an index of EBV for conformation, fertility, and udder health traits; and 3) combining genetic evaluations for DHL and IHL into an overall genetic evaluation for herd life (HL). The present study describes changes made in the genetic evaluation model for DHL, in which the first lactation is divided into 3 periods of survival. The revised model for IHL includes other traits such as fertility and health traits. The method to combine DHL and IHL in the overall index (HL) was as previously described by Jairath et al. (1998).

\section{Trait Definition and Model for DHL}

Sewalem et al. (2005) studied genetic parameters of herd life for Canadian dairy breeds using a Weibull proportional hazards model. Results from that study showed that there were 2 critical periods during the first lactation in which the relative risk of a cow being culled was very high, at 80 and 235 DIM. In the present analysis, 120 and 240 DIM were chosen as cut-off points because the risk of culling was lowest at these points. For the first 2 traits $\left(\mathrm{S}_{\mathrm{a}}\right.$ and $\left.\mathrm{S} 1_{\mathrm{b}}\right)$, a 90 -d opportunity window was used, and for the last 3 traits $\left(\mathrm{S} 1_{\mathrm{c}}, \mathrm{S} 2\right.$, and S3), a 1.5-yr opportunity window was used, allowing the cow a chance to have the next test-day record or another calving. Survival in each of the 5 traits was coded as 0 if the cow was culled during that time period, as 1 if the cow survived during that lactation, and as missing or undefined if the cow had not had an opportunity to begin or complete that lactation. The phenotypic means for the 5 traits were $97.5,92.0,82.9,69.2$, and $61.4 \%$ for $\mathrm{S} 1_{\mathrm{a}}, \mathrm{S} 1_{\mathrm{b}}, \mathrm{S} 1_{\mathrm{c}}, \mathrm{S} 2$, and $\mathrm{S} 3$, respectively.

The survival data were analyzed using a multipletrait animal model in which the 5 survival traits were considered as different traits. The following model was used for genetic parameter estimation:

$$
\begin{gathered}
y_{i j k m}=h_{i m}+\operatorname{rhs}_{j m}+\left(\operatorname{age}_{k}\right)_{m}+\left(\operatorname{prot}_{\mathrm{k}} \times \operatorname{rhs}_{j}\right)_{j m} \\
+\left(\operatorname{prot}_{\mathrm{k}}\right)_{\mathrm{m}}+\left(\text { fat }_{\mathrm{k}}\right)_{\mathrm{m}}+\operatorname{animal}_{\mathrm{km}}+\mathrm{e}_{\mathrm{ijkm}}
\end{gathered}
$$

where $y_{\mathrm{ijkm}}=$ observation for survival ( 0 or 1$)$ in trait $m(m=1$ to 5$)$ on cow $k$ that calved in herd-year $i$; $\mathrm{h}_{\mathrm{yim}}=$ fixed effect of herd-year of calving $i$ for trait $m ; \operatorname{rhs}_{j m}=$ fixed effect of subclass $j$ for registry status (2 classes) $\times$ herd size change (3 classes) $\times$ season of calving $(4$ classes) for trait $m$; $\left(\text { age }_{\mathrm{k}}\right)_{\mathrm{m}}=$ linear and quadratic regressions of survival in trait $m$ on age at first calving $k$; trait $m$ on prot $_{\mathrm{km}}$ by rhs $\mathrm{rm}_{\mathrm{jm}}$ subclasses, where $\operatorname{prot}_{\mathrm{k}}$ is the normal rank of the cow for protein yield in first lactation within herd-year of first calving; $\left(\operatorname{prot}_{\mathrm{k}}\right)_{\mathrm{m}}$ and $\left(f^{a} t_{k}\right)_{m}=$ linear, quadratic, and cubic regressions of survival in trait $m$ on the cow's normal ranks for protein and fat yield in lactation 1 within herd-year of first calving; animal $_{\mathrm{km}}=$ random additive genetic effect of animal $k$ for survival in trait $m$; and $\mathrm{e}_{\mathrm{ijkm}}=$ random residual. Contemporary groups of herd-year of calving were formed in relation to the dairy quota year (July to June) rather than a calendar year because of the impact of the quota system in Canada on culling. Genetic parameters for Holsteins were estimated using the software package VCE-5 (Groeneveld, 1998).

Estimates of genetic parameters for $\mathrm{S}_{\mathrm{a}}, \mathrm{S} 1_{\mathrm{b}}, \mathrm{S} 1_{\mathrm{c}}, \mathrm{S} 2$, and $\mathrm{S} 3$ are presented in Table 1 . The genetic variances for the first 2 traits $\left(\mathrm{S}_{\mathrm{a}}\right.$ and $\left.\mathrm{S} 1_{\mathrm{b}}\right)$ were small compared with the other traits. This was expected because the phenotypic variation within the first 2 traits was very small. Generally, similar low heritability values of herd life were reported (Jairath et al., 1998; Sewalem et al., 2005; VanRaden, et al., 2006). Genetic correlations among the 5 traits were moderate to high ranging from 0.73 to 0.97 (Table 1 ).

\section{Genetic Evaluation for DHL}

Data for the genetic evaluation of DHL were obtained from lactation records used for the May 2005 genetic evaluations for production. Using the above genetic parameters, a genetic evaluation of the 5 survival traits was carried out for Holsteins using a multiple-trait ani- 
Table 1. Estimates of heritability and genetic correlation for the 5 herd life traits of Canadian Holstein (heritabilities are on the diagonal, genetic correlations are above the diagonal)

\begin{tabular}{|c|c|c|c|c|c|c|}
\hline \multirow[b]{2}{*}{ Trait } & \multirow{2}{*}{$\begin{array}{c}\text { Genetic } \\
\text { variance }\end{array}$} & \multicolumn{5}{|c|}{ Traits } \\
\hline & & $\mathrm{S} 1_{\mathrm{a}}$ & $\mathrm{S} 1_{\mathrm{b}}$ & $\mathrm{S} 1_{\mathrm{c}}$ & $\mathrm{S} 2$ & S3 \\
\hline From first calving to $120 \mathrm{DIM}\left(\mathrm{S} 1_{\mathrm{a}}\right)$ & $1.5 \times 10^{-3}$ & 0.01 & 0.97 & 0.94 & 0.85 & 0.78 \\
\hline From 120 DIM to 240 DIM $\left(\mathrm{S}_{\mathrm{b}}\right)$ & $8.6 \times 10^{-3}$ & & 0.01 & 0.98 & 0.85 & 0.78 \\
\hline From 240 DIM to second calving $\left(\mathrm{S} 1_{c}\right)$ & $2.7 \times 10^{-2}$ & & & 0.02 & 0.81 & 0.73 \\
\hline Through second lactation (S2) & $7.9 \times 10^{-2}$ & & & & 0.04 & 0.76 \\
\hline Through third lactation (S3) & $1.1 \times 10^{-1}$ & & & & & 0.05 \\
\hline
\end{tabular}

mal model. A total of 3,280,037 cows and 102,126 sires were evaluated. The 5 individual EBV were combined by considering the average survival rate of daughters for each bull.

Let $S_{i}=$ the mean survival rate for trait $i+$ sire ETA for trait $i$, and the cumulative survival rate for trait $i$ is $C_{i}=\prod_{i=1}^{6} S_{i}$ and $C_{6}=0$.

$$
D H L=\frac{\left(\sum_{i=1}^{6}\left(C_{i-1}-C_{i}\right) \times\left(N_{i}+D_{i}\right)\right)+K}{365}
$$

where DHL is the direct herd life, $N_{i}=$ mean calving interval in days for trait $i$ ( $\mathrm{n}=0$ for trait 1,2 , and 3 ), $D_{i}$ are the means days of production for cows culled in trait $i$, and $K$ is a constant; that is, the expected the mean calving intervals and average days of production for cows culled after the fourth calving.

The correlations among the 5 traits and the correlations of each trait with combined DHL are presented in Table 2. Correlations among EBV of the 5 traits were very high, ranging from 0.90 to 0.99 . Correlations of EBV of the 5 traits to the overall DHL were all $>0.95$. Parallel genetic evaluation runs of the new (5-trait) and old (3-trait) systems for genetic evaluation of herd life were performed using the August 2006 data set. The correlations of DHL between the old and new systems of genetic evaluations ranged from 0.89 to 0.98 depending on the number of daughters per sire. As the number of daughters per sire increased, the correlation increased.

\section{Genetic Evaluations of IHL}

To obtain accurate prediction of DHL, only Holstein bulls with at least 50 daughters in third lactation ere included. This strong editing criterion resulted in a small sample of bulls with high reliability for DHL EBV. In total, 252 bulls born after 1986 were used. All available sire EBV were fitted in a multiple regression using the stepwise procedure of SAS (SAS Institute, 2006). The minimum threshold of significance to remain in the model was $P<0.01$. The final equation to predict DHL had an adjusted $\mathrm{R}^{2}$ of 0.50 and included EBV (relative emphasis) for body capacity $(-6 \%)$, feet and legs $(3 \%)$, overall udder (16\%), rump angle (11\%), SCS $(-14 \%)$, milking speed (12\%), nonreturn rate in heat at $56 \mathrm{~d}$ for cows (13\%), and interval from calving to first service $(-22 \%)$. Body capacity has been recently replaced by dairy strength with the same emphasis and sign. Given the impossibility of obtaining relevant sample size for the other breeds, the predicted formula for Holstein was also applied to all other Canadian dairy breeds.

\section{Overall Index of $H L$}

A multiple-trait procedure based on multiple-trait across-country (Jairath et al., 1998) methodology for combining sire evaluations based on survival and indi-

Table 2. Correlations among the 5 traits and sire direct herd life (DHL) for Canadian Holsteins

\begin{tabular}{lccccc}
\hline & \multicolumn{5}{c}{ Traits } \\
\cline { 2 - 6 } Trait & $\mathrm{S} 1_{\mathrm{a}}{ }^{1}$ & $\mathrm{~S} 1_{\mathrm{b}}$ & $\mathrm{S} 1_{\mathrm{c}}$ & $\mathrm{S} 2$ & $\mathrm{~S} 3$ \\
\hline From 120 DIM to 240 DIM (S1 ${ }_{\mathrm{b}}$ ) & 0.993 & & & & \\
From 240 DIM to second calving (S1 $)$ & 0.994 & 0.992 & & & \\
Survival through second lactation (S2) & 0.976 & 0.958 & 0.956 & 0.969 & 0.989 \\
Survival through third lactation (S3) & 0.944 & 0.924 & 0.918 & 0.993 & \\
DHL & 0.978 & 0.961 & 0.958 & &
\end{tabular}

${ }^{1} \mathrm{~S} 1_{\mathrm{a}}=$ from first calving to 120 DIM. 
rect predictors was used for the overall evaluation of herd life in Canada. A total of 8,374 sires were included in the analysis.

In conclusion, the new system of herd life evaluation with 5 traits has been used for national evaluation of herd life for all Canadian dairy breeds (Ayrshire, Brown Swiss, Canadienne, Guernsey, Holstein, Jersey, and Milking Shorthorn) since February 2006. A DHL EBV is obtained for each bull by 7 mo after first calving of their daughters instead of $24 \mathrm{mo}$ in the previous old system of evaluation herd life. The correlation of EBV between the new system and old system of evaluation was high, ranging from 0.89 to 0.98 .

\section{REFERENCES}

Allaire, F. R., and J. P. Gibson. 1992. Genetic value of herd life adjusted for milk production. J. Dairy Sci. 75:1349-1356.

Brotherstone, S., R. F. Veerkamp, and W. G. Hill. 1998. Predicting breeding values for herd life of Holstein-Friesian dairy cattle from lifespan and type. Anim. Sci. 67:405-411.

Congleton, W. R., Jr., and L. W. King. 1984. Profitability of dairy cow herd life. J. Dairy Sci. 67:661-674.

Dekkers, J. C. M. 1993. Theoretical basis for genetic parameters of herd life and effects on response to selection. J. Dairy Sci. 76:1433-1443.
Ducrocq, V. 2002. A piecewise Weibull mixed model for the analysis of length of productive life of dairy cows. Proc. 7th World Congr. Genet. Appl. Livest. Prod., Montpellier, France. Communication No. $20-04$.

Groeneveld, E. 1998. VCE User's guide. Version 4.2. Institute of Animal Husbandry and Animal Sciences, Mariensee, Germany.

International Bull Evaluation Service. 2005. Interbull routine genetic evaluation for direct herd life, February 2005. http://www-interbull.slu.se/longevity/framesida-long.htm Accessed March, 2005.

Jairath, L., J. C. M. Dekkers, L. R. Schaeffer, Z. Liu, E. B. Burnside, and B. Kolstad. 1998. Genetic evaluation for herd life in Canada. J. Dairy Sci. 81:550-562.

SAS Institute. 2006. SAS User's Guide: Statistics. Version 8.2 ed. SAS Institute, Inc., Cary, NC.

Sewalem, A., G. J. Kistemaker, V. Ducrocq, and B. J. Van Doormaal. 2005. Genetic analysis of herd life in Canadian dairy cattle on a lactation basis using a Weibull proportional hazards model. J. Dairy Sci. 88:368-375.

van Arendonk, J. A. M. 1991. Use of profit equations to determine relative economic value of dairy cattle herd life and production from field data. J. Dairy Sci. 74:1101-1107.

VanRaden, P. M., and E. J. H. Klaaskate. 1993. Genetic evaluation of length of productive life including predicted longevity of live cows. J. Dairy Sci. 76:2758-2764.

VanRaden, P. M., C. M. B. Dematawewa, R. E. Pearson, and M. E. Tooker. 2006. Productive life including all lactations and longer lactations with diminishing credits. J. Dairy Sci. 89:3213-3220.

Vollema, A. R., S. van der Beek, A. G. F. Harbers, and G. de Jong. 2000. Genetic evaluation for longevity of Dutch dairy bulls. J. Dairy Sci. 83:2629-2639. 